\title{
Cold-adapted yeasts from Antarctica and the Italian Alps-description of three novel species: Mrakia robertii sp. nov., Mrakia blollopis sp. nov. and Mrakiella niccombsii sp. nov.
}

\author{
Skye Robin Thomas-Hall • Benedetta Turchetti • \\ Pietro Buzzini • Eva Branda • Teun Boekhout • \\ Bart Theelen $\cdot$ Kenneth Watson
}

Received: 31 July 2009/Accepted: 9 October 2009/Published online: 7 November 2009

(C) The Author(s) 2009. This article is published with open access at Springerlink.com

\begin{abstract}
Worldwide glaciers are annually retreating due to global overheating and this phenomenon determines the potential lost of microbial diversity represented by psychrophilic microbial population sharing these peculiar habitats. In this context, yeast strains, all unable to grow above $20^{\circ} \mathrm{C}$, consisting of 42 strains from Antarctic soil and 14 strains isolated from Alpine Glacier, were isolated and grouped together based on similar morphological and physiological characteristics. Sequences of the D1/D2 and ITS regions of the ribosomal DNA confirmed the previous analyses and demonstrated that the strains belong to unknown species. Three new species are proposed: Mrakia robertii sp. nov. (type strain CBS 8912), Mrakia blollopis sp. nov. (type strain CBS 8921) and a related anamorphic species Mrakiella niccombsii sp. nov. (type strain CBS 8917). Phylogenetic analysis of the ITS region revealed that the new proposed species were closely related to each other within the Mrakia clade in the order Cystofilobasidiales, class Tremellomycetes. The Mrakia clade now
\end{abstract}

Communicated by A. Oren.

Electronic supplementary material The online version of this article (doi:10.1007/s00792-009-0286-7) contains supplementary material, which is available to authorized users.

S. R. Thomas-Hall $(\bowtie) \cdot$ K. Watson

School of Biological Sciences, University of New England,

Armidale, NSW, Australia

e-mail: skyethomashall@gmail.com

B. Turchetti · P. Buzzini · E. Branda

Department of Applied Biology, University of Perugia,

Perugia, Italy

T. Boekhout $\cdot$ B. Theelen

Yeast Research Group, CBS-KNAW Fungal Diversity Centre,

Utrecht, The Netherlands contains 8 sub-clades. Teliospores were observed in all strains except CBS 8918 and for the Mrakiella niccombsii strains.

Keywords Antarctic microbiology · Cold adaptation · Molecular phylogeny · Psychrophiles · Taxonomy

\section{Introduction}

Strains belonging to the genera Mrakia and Mrakiella have been found in many cold climates throughout the world, such as Antarctica (Di Menna 1966a; Xin and Zhou 2007); glacier-preserved ascolichens in Greenland (Depriest et al. 2000a, b), central Russia (Maksimova and Chernov 2004), Western Siberia and Alaska (Poliakova et al. 2001); the Alps from glacier cryoconite, glacial sediment, ice and melting water (Margesin et al. 2002; Turchetti et al. 2008); glaciers of Argentina (de García et al. 2007) and frozen fish in Japan (Komagata and Nakase 1965). Di Menna (1966b) found Mrakia to be the dominant yeast genus in soil of Antarctica, representing 24\% of the yeast species isolated in that study.

All the Mrakia and Mrakiella (Margesin and Fell 2008) species described till now (the only exception is Mrakia curviuscula that is doubtfully assigned to this genus) have an optimal temperature of growth of approximately $12-15^{\circ} \mathrm{C}$ and are not able to grow at temperatures above $20^{\circ} \mathrm{C}$ and thus can be defined as obligate psychrophilic yeasts (Watson 1987; Raspor and Zupan 2006).

The ability of psychrophilic yeasts to grow at low temperatures and even below the freezing point (Panikov and Sizova 2007) suggested their capability of degrading organic compounds at low temperatures and consequently their biologically active presence in the nutrient cycle of 
glacial habitats (Welander 2005; Lambo and Patel 2006). Biotechnological utilizations of psychrophilic yeast species relate to their role in low temperature fermentations and their ability to produce cold-active enzymes (Scorzetti et al. 2000; Kourkoutas et al. 2002; Nakagawa et al. 2004; Margesin et al. 2005; Pfeffer et al. 2006; Liu et al. 2006; Brizzio et al. 2007).

In previous studies focused on the characterization of isolates from the Vestfold Hills area of Antarctica and from two glaciers in the Italian Alps (Thomas-Hall and Watson 2002; Turchetti et al. 2008), cold-tolerant yeast species were described; Mrakia species were present in high density in almost all the material sampled and appeared to be amongst the most dominating yeast species thus supporting the observations of Di Menna (1966b).

In the present paper, the description of novel coldadapted species, Mrakia robertii sp. nov., Mrakia blollopis sp. nov. and a related species Mrakiella niccombsii sp. nov., is proposed.

\section{Materials and methods}

\section{Yeast isolation}

The yeast strains described in this study are listed in Table 1.

A study on the fungal diversity in the Vestfold Hills area of Davis Base, Antarctica, identified 327 yeast isolates from 185 soil samples. Soil samples were stored at $-10^{\circ} \mathrm{C}$ in quarantine at the University of Tasmania, Hobart. Fortytwo isolates were grouped together based on morphological characteristics. One-dimensional polyacrylamide gel electrophoresis (1D-PAGE) of whole-cell protein extracts and phylogenetic analysis of D1/D2 and ITS regions confirmed the grouping of the strains and demonstrated a close relation with the Mrakia clade. Subsequently, 13 of the 42 Mrakia isolates are described in detail in this taxonomic study.

Sediments, ice and melting water from Italian Alps were collected from the Forni $\left(46^{\circ} 23^{\prime} \mathrm{N}, 10^{\circ} 35^{\prime} \mathrm{E}\right)$ and the Sforzellina Glaciers $\left(46^{\circ} 20^{\prime} \mathrm{N}, 10^{\circ} 30^{\prime} \mathrm{E}\right)$. Fourteen Mrakia sp. strains were isolated and identified as described in Turchetti et al. (2008).

All cultures were maintained on YEP plates and as aqueous stocks or lyophilized at $4^{\circ} \mathrm{C}$, with long-term storage in glycerol stocks at $-80^{\circ} \mathrm{C}$.

Physiological tests and morphology

Physiological tests were performed according to the protocols described by Yarrow (1998). All tests were performed in duplicate at $10-15^{\circ} \mathrm{C}$ and results recorded at
2 and 4 weeks after inoculation. Colony morphology images were taken using a stereo microscope coupled with the Dage 3-chip CCD camera or colonies were photographed directly with a Nikon zoom digital camera, COOLPIX950. Standard light microscopy was employed using a Zeiss Axioskop microscope and Nomarski optics coupled with a Dage 3-chip CCD camera, Model DC-330E video camera for imaging. Cell size and morphology were determined by scanning electron microscopy (JEOL model JSM 5800LV, accelerating voltage $15 \mathrm{kV}$ ) using an improved fixation procedure for yeasts (Hanschke and Schauer 1996).

1D-PAGE of whole-cell protein extracts and lipid analysis

Protein extractions and SDS-PAGE were performed as previously described (Thomas-Hall et al. 2002). Fatty acid extractions were performed according to Rule (1996). Samples were analysed as described by Swan and Watson (1997).

Phylogenetic analysis

The D1/D2 domains of the large subunit (LSU) rRNA gene region and the Internal Transcribed Spacers (ITS1 and 2 regions) including the 5.8S rRNA gene were amplified by cycle sequencing using the following forward and reverse primers, respectively: NL1 5'-GCATATCAATAAGCGG AGGAAAAG and RLR3 5'-GGTCCGTGTTTCAAGAC for LSU; ITS1 $5^{\prime}$-TCCGTAGGTGAACCTGCGG and ITS4 5'-TCCTCCGCTTATTGATATGC for the ITS regions. The sequences were obtained with an ABI PRISM 3730XL Capillary Sequencer using the standard protocol (Thomas-Hall et al. 2002). Sequence analysis of the rDNA IGS region was performed as described by Diaz and Fell (2000). The sequences were aligned, analysed and corrected using Seqman ${ }^{\mathrm{TM}}$ II and MegAlign ${ }^{\mathrm{TM}}$ (DNAStar Inc., UK); alignments were checked and corrected manually. Phylogenetic analysis was performed using Molecular Evolutionary Genetics Analysis (MEGA) Software Version 4.0 (Tamura et al. 2007) using maximum parsimony analysis. Bootstrap analysis (1,000 replicates) was performed using a parsimonious heuristic search with random addition of sequences (100 replicates).

\section{Results}

Phylogenetic analysis

Accession data of the species included in the phylogenetic analyses are present in Table 1. 
Table 1 List of the yeast strains considered in the present study: strain accession numbers, substrate and locality of isolation, GenBank accession number of LSU and ITS1 and 2 sequences

\begin{tabular}{|c|c|c|c|c|c|c|}
\hline \multirow[t]{2}{*}{ Phylogenic group } & \multirow[t]{2}{*}{ Species } & \multirow[t]{2}{*}{ Strain } & \multirow[t]{2}{*}{ Isolation source } & \multirow[t]{2}{*}{ Sample } & \multicolumn{2}{|c|}{$\begin{array}{l}\text { GenBank accession } \\
\text { number }\end{array}$} \\
\hline & & & & & LSU & ITS 1 and 2 \\
\hline \multirow[t]{4}{*}{ Group 1} & Mrakia frigida & CBS $5270^{\mathrm{T}}$ & Scott Base Antarctica & Snow and soil & AF075463 & AF144483 \\
\hline & Mrakia nivalis & CBS 5266 & Scott Base Antarctica & Soil & AF189849 & AF144484 \\
\hline & Cryptococcus curiosus & CBS 5688 & Japan & Frozen fish & AF189847 & AF144482 \\
\hline & Mrakia frigida & CBS $8907^{\mathrm{a}}$ & Lichen Valley Antarctica & Snow petrel & AY038806 & AY038836 \\
\hline \multirow[t]{9}{*}{ Group 2} & Mrakia robertii & CBS $8912^{\mathrm{T} \text { a }}$ & Mossell Lake Antarctica & Soil and lichen & AY038811 & AY038829 \\
\hline & Mrakia robertii & CBS $8918^{a}$ & Moss Cirque Antarctica & Soil & AY038805 & AY038834 \\
\hline & Mrakia robertii & CBS $8919^{a}$ & Lichen Valley Antarctica & Soil and lichen & AY038804 & AY038835 \\
\hline & Mrakia robertii & DBVPG $4728^{a}$ & Forni Glacier Alps & Subglacial sediments & EF643720 & FJ487625 \\
\hline & Mrakia robertii & DBVPG $4752^{a}$ & Sforzellina Glacier Alps & Subglacial sediments & FJ487623 & FJ487626 \\
\hline & Mrakia robertii & DBVPG $4775^{\mathrm{a}}$ & Forni Glacier Alps & Melting water & FJ487624 & FJ487627 \\
\hline & Mrakia robertii & DBVPG $4782^{a}$ & Sforzellina Glacier Alps & Melting water & EF643731 & FJ487628 \\
\hline & Uncultured basidiomycota & 96-G6 & Greenland & Subfossil lichens & & AF294943 \\
\hline & Uncultured basidiomycota & $96-G 11$ & Greenland & Subfossil lichens & & AF294940 \\
\hline \multirow[t]{6}{*}{ Group 3} & Mrakia gelida & CBS $5272^{\mathrm{T}}$ & Scott Base Antarctica & Soil & AF189831 & AF144485 \\
\hline & Mrakia stokesii & CBS 5917 & Bouvet Island Antarctica & Snow and soil & AF189830 & AF144486 \\
\hline & Mrakia gelida & CBS $8914^{\mathrm{a}}$ & Lichen Valley Antarctica & Soil and lichen & AY038807 & AY038833 \\
\hline & Mrakia gelida & CBS $8922^{\mathrm{a}}$ & Moss Cirque Antarctica & Soil and lichen & AY038809 & AY038831 \\
\hline & Uncultured basidiomycota & 96-G1 & Greenland & Subfossil lichens & AF294944 & AF294941 \\
\hline & Uncultured basidiomycota & $96-\mathrm{G} 3$ & Greenland & Subfossil lichens & AF294945 & AF294942 \\
\hline Group 4 & Mrakia psychrophila & AS $2.1971^{\mathrm{T}}$ & Fildes Peninsula Antarctica & Soil & EU224266 & EU224267 \\
\hline \multirow[t]{3}{*}{ Group 5} & Mrakia blollopis & CBS $8921^{\mathrm{T} \text { a }}$ & Marine Plain Antarctica & Soil & AY038814 & AY038826 \\
\hline & Mrakia blollopis & CBS $8909^{\mathrm{a}}$ & Moss Cirque Antarctica & Soil & AY038812 & AY038828 \\
\hline & Mrakia blollopis & CBS $8910^{a}$ & Moss Cirque Antarctica & Soil, benthic, algal mat & AY038813 & AY038827 \\
\hline \multirow[t]{2}{*}{ Group 6} & Mrakiella cryoconiti & CBS $10834^{\mathrm{T}}$ & Alps & Glacier cryoconite & AJ866978 & AJ866976 \\
\hline & Mrakiella cryoconiti & CBS 10835 & North Siberia & Sediments & AJ866979 & AJ866977 \\
\hline \multirow[t]{3}{*}{ Group 7} & Mrakiella aquatica & CBS $5443^{\mathrm{T}}$ & Malham Tarn, UK & Scum on water & AF075470 & AF410469 \\
\hline & Mrakiella aquatica & Strain $\mathrm{H} 2$ & Iceland & Frozen soil & AY052480 & AY052488 \\
\hline & Mrakiella aquatica & Strain H1 & Iceland & Frozen soil & AY052479 & AY052487 \\
\hline \multirow[t]{2}{*}{ Group 8} & Mrakiella niccombsii & CBS $8917^{\mathrm{T} \text { a }}$ & Vestvold Hills Antarctica & Lichen & AY029345 & AY029346 \\
\hline & Mrakiella niccombsii & CBS $8924^{\mathrm{a}}$ & Vestvold Hills Antarctica & Soil and lichen & AY029345 & AY029346 \\
\hline Outgroup & Guehomyces pullulans & CBS $2532^{\mathrm{T}}$ & & Air & AF105394 & AF444417 \\
\hline
\end{tabular}

Phylogenic groups are also presented

${ }^{a}$ Strains come from this study. Other data were obtained from the following references: Kurtzman and Fell (1998), Depriest et al. (2000a), Xin and Zhou (2007), Margesin and Fell (2008), Birgisson et al. (2003), www.ncbi.nlm.nih.gov

Mrakia gelida, Mrakia frigida as well as CBS 8912, CBS 8918, CBS 8919, DBVPG 4728, DBVPG 4752, DBVPG 4775 and DBVPG 4782 strains presented the same D1/D2 LSU rRNA sequences (Fig. 1); this is a characteristic of the genus and it is the reason why this information could not be used to separate some of the species inside the genus Mrakia. Strains that presented different D1/D2 LSU sequence were as follows: CBS $8912^{\mathrm{T}}$ (by $1 \mathrm{nt}$ ), CBS 8909 , CBS 8910 (by $2 \mathrm{nt}$ ) and CBS $8921^{\mathrm{T}}$ (by $3 \mathrm{nt}$ ); whilst the recently described species Mrakia psychrophila CBS $5270^{\mathrm{T}}$ varied by $3 \mathrm{nt}$. For species M. curviuscula CBS
$9136^{\mathrm{T}}$, the D1/D2 sequence data aligned with Cryptococcus huempii CBS $8186^{\mathrm{T}}$. These two species fall in a different to clade to the other Mrakia species. In addition to this, the strain does not ferment, in contrast to all other strains in the Mrakia genus. These data suggest that the isolate is probably misplaced in the Mrakia genus and should be reclassified (Margesin and Fell 2008). Two other isolates, CBS 8917 and CBS 8924 (these strains presented identical LSU sequences), were identified from the D1/D2 sequence analysis to be closely related to the Mrakia clade; the closest described species was Mrakiella aquatica CBS 
Fig. 1 Phylogeny of the Mrakia/Mrakiella clade. Maximum parsimony tree of D1/D2 LSU rRNA gene sequences. Bootstrap percentages from 1,000 replications shown on the branches. Guehomyces pullulans CBS $2532^{\mathrm{T}}$ was used as the outgroup

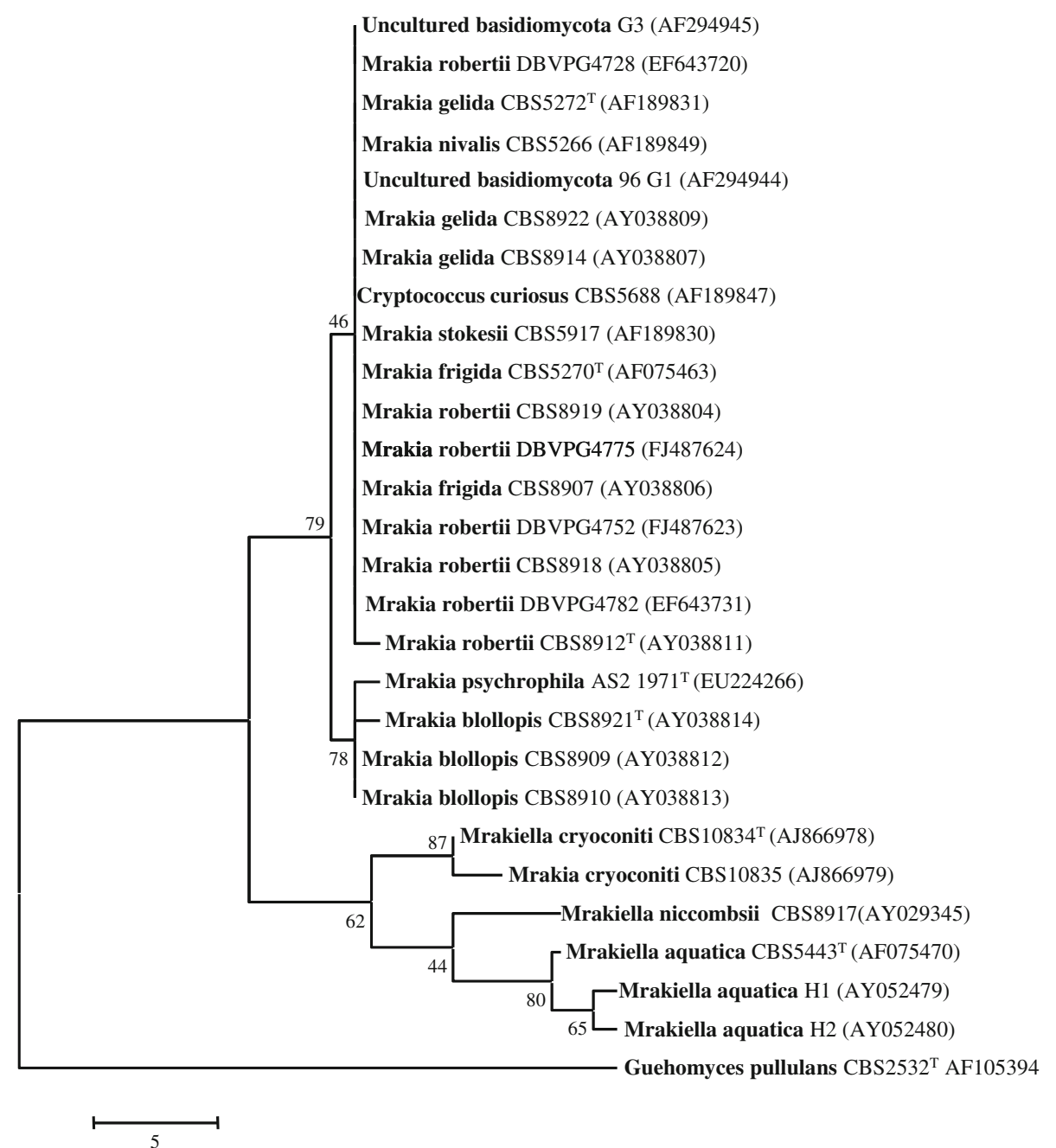

$5443^{\mathrm{T}}$ (previously Cryptococcus aquaticus, renamed by Margesin and Fell 2008), differing by 10 nt. Shortly after these isolates were identified and their sequences submitted, H. Vishniac (personal communication) identified a similar isolate from Providenya, Russia, which was deposited as CBS 9300. Approximately half of the D1/D2 region was sequenced in this strain and found to be identical to the sequences of CBS $8917^{\mathrm{T}}$ and CBS 8924. However, these data were not included in the current phylogenetic analysis as only a partial sequence was available for CBS 9300. Moreover, it should not be concluded on the basis of these 350 identical nucleotides that isolate CBS 9300 is con-specific to CBS $8917^{\mathrm{T}}$ and CBS 8924. Further comparisons are necessary to confirm its identity and sequencing of the ITS region would be informative as would protein fingerprint comparison or nDNA hybridisation with the other strains.

The analysis of the ITS regions of the ribosomal DNA identified eight clusters inside the Mrakia clade which are labelled 1-8 (Fig. 2). Group 1, Mrakia robertii composed of CBS 8912 ${ }^{\mathrm{T}}$, CBS 8918, CBS 8919, DBVPG 4728,
DBVPG 4752, DBVPG 4775 and DBVPG 4782 (differed from CBS $8912^{\mathrm{T}}$ by 3 or $4 \mathrm{nt}$ ) and 2 uncultured basidiomycetous strains from Greenland lichens (Depriest et al. 2000a, b) that showed 4 and 6 different base pairs from CBS $8912^{\mathrm{T}}$. Group 2, Mrakia gelida constituted of CBS 5272 ${ }^{\mathrm{T}}$, CBS 5917, and CBS 8914 and CBS 8922 and two uncultured basidiomycetes isolates from Greenland lichens (Depriest et al. 2000a, b) differed from CBS $5272^{\mathrm{T}}$ by 1 and $5 \mathrm{nt}$, respectively. Group 3, Mrakia psychrophila consisted of only the type strain AS $2.1971^{\mathrm{T}}$. Group 4, Mrakia blollopis consisted of CBS $8921^{\mathrm{T}}$, CBS 8909 (differed from CBS $8921^{\mathrm{T}}$ by $3 \mathrm{nt}$ ) and CBS 8910 (differed from CBS $8921^{\mathrm{T}}$ by $4 \mathrm{nt}$ ). M. psychrophila was most closely aligned with the group 4 strains, but differed from CBS $8921^{\mathrm{T}}$ by $8 \mathrm{nt}$. Group 5, Mrakia frigida consisted of CBS 5266, CBS 5270 and CBS 5688, which had identical sequence and CBS 8907 which differed by 4 nt. Group 6, Mrakiella cryoconiti composed of CBS $10834^{\mathrm{T}}$ and CBS 10835 (2 different nt). Group 7, Mrakiella niccombsii consisted of two strains: CBS $8917^{\mathrm{T}}$ and CBS 8924. The phylogenetic data from the ITS region consolidated the 
Physiology tests

\section{$\begin{array}{lllllll}1 & 2 & 3 & 4 & 5 & 6 & 7\end{array}$}

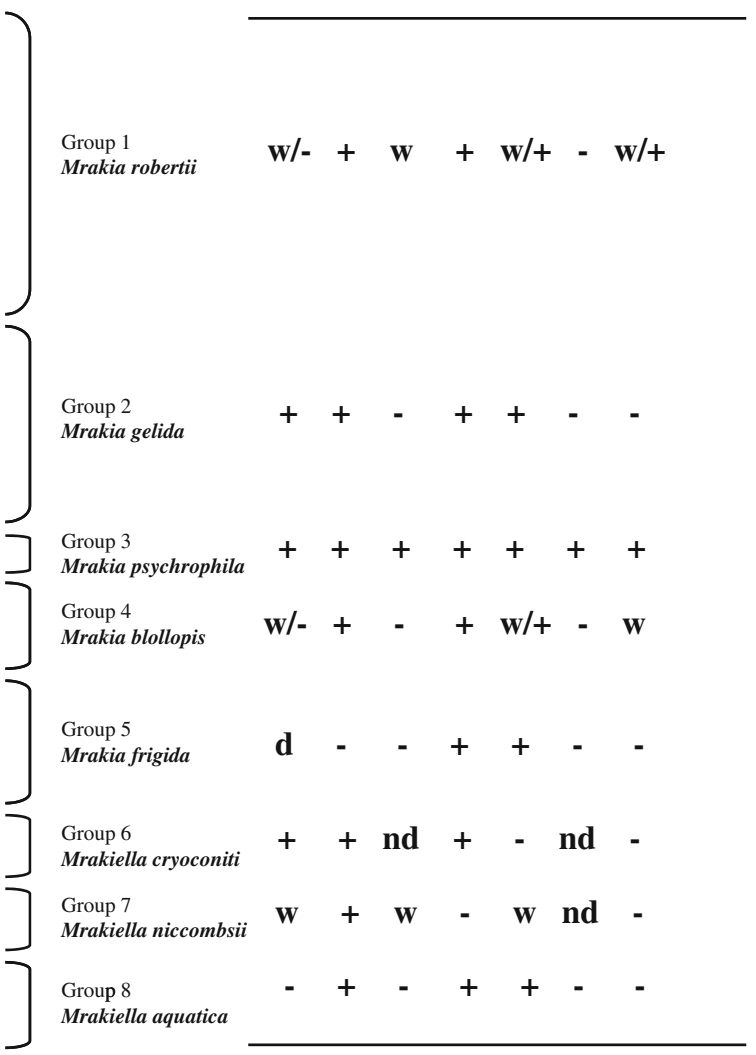

5

Fig. 2 Phylogeny of the Mrakia/Mrakiella clade. Maximum parsimony tree of ITS1, 5.8S rRNA and ITS2 gene sequences. Bootstrap percentages from 1,000 replications shown on the branches. Guehomyces pullulans CBS $2532^{\mathrm{T}}$ was used as the outgroup. Each species is represented by a group number: $M$. robertii, group $1 ; M$. gelida, group 2; M. psychrophila, group 3; M. blollopis, group 4; M. frigida,

D1/D2 data with no variation observed between CBS $8917^{\mathrm{T}}$ and CBS 8924, the closest phylogenetic relation was again $M r$. aquatica, differing by 8 nt. Two additional strains of $M r$. aquatica (strains $\mathrm{H} 1$ and $\mathrm{H} 2$ isolated from Heidmork, Iceland; Birgisson et al. 2003) were also included in both phylogenetic analyses, these differed from CBS $5443^{\mathrm{T}}$ by $4 \mathrm{nt}$ in the D1/D2 region and by 7 and $12 \mathrm{nt}$ in the ITS region. This level of variation warrants further study into the relationship amongst these strains, to assess if they represent distinct species. The last clade, group 8, Mrakiella aquatica consisted of only CBS $5443^{\mathrm{T}}$.

\section{Morphology}

Each strain was streaked out on YEP plates and inoculated in YEP broth, incubated at $15^{\circ} \mathrm{C}$ and observed after 1 and group 5; Mr. cryoconiti, group 6; Mr. niccombsii, group 7; Mr. aquatica, group 8. Main physiology test results characterizing each species are shown. Test 1 Assimilation of $\mathrm{D}$-arabinose, test 2 assimilation of maltose, test 3 assimilation of inulin, test 4 assimilation of ribitol/adonitol, test 5 assimilation of citrate, test 6 assimilation of ethylamine, test 7 growth in vitamin-free medium

3 weeks but also after 2, 3, 6, 9, and 15 months. When teliospores were observed, they were transferred to $\mathrm{dH}_{2} \mathrm{O}$ and incubated at $6^{\circ} \mathrm{C}$ for 3 weeks before germinated on nutrient-free agar $(2 \%)$ at $6^{\circ} \mathrm{C}$. Isolates were commonly cultured at $4^{\circ} \mathrm{C}$ to prolong storage time of the working stock cultures; at this temperature, all described cultures had strong growth.

CBS 8912, CBS 8918, CBS 8919 and all the strains isolated from Alpine Glaciers ( $M$. robertii, group 1 in phylogenetic ITS sequences analysis) showed similar morphological aspects in YEP broth: the cells appeared ovoid-elongate and occurred singly or in parent-bud pairs; short hyphae and pseudohyphae were observed in mature culture (4 weeks). The colonies were mostly white cream colour, butyrous and appeared to be fringed by membranous mycelium. Both pseudo- and true hyphae were 
observed in colonies grown in MEA and PDA. Terminal and intercalary teliospores occurred in CBS 8912 and CBS 8919.

The strains CBS 8921, CBS 8909 and CBS 8910 (M. blollopis, group 4) presented spheroidal to ovoid cells that occurred singly or in short clusters of two or three cells when grown in YEP broth; the cells from this group of isolates were generally larger $[(2-4) \times(3.5-7) \mu \mathrm{m}]$ than observed in all other Mrakia groups. The colonies were butyrous with extensive spreading of hyphae; the colour was white cream turning into yellow-white in 4-5-weekold colonies.

The cells of CBS 8917 and CBS 8924 (Mr. niccombsii, group 7) were similar in YEP broth, elongate to ovoid, $(2-3) \times(4-7) \mu \mathrm{m}$. On YEP agar, the colonies were white cream, butyrous, and in older cultures, pseudohyphae extended occasionally into and along the agar. In these strains, no teliospores were observed in any media tested.

In YEP, MEA and PDA, budding was always polar for all the strains studied. On nitrogen base agar with no carbon source (except agar), the colonies of all the strains studied were small and had extensive growth hyphae spreading out and no teliospores occurred; on carbon base agar with no nitrogen source, colonies were small and butyrous, had extensive hyphal fringes, and teliospores occurred terminally and intercalary in all strains except for all DBVPG strains, CBS 8918, CBS 8917 and CBS 8924. Additional description of each isolates and images of cellular and colony morphology are presented in the Supplementary data.

\section{Physiology}

Carbohydrate assimilation tests and other physiological characteristics that can be used to differentiate all the strains are presented in Table 2 of the Supplementary data.

Physiological data presented in the table were taken not only from this study, but also from the CBS database (www.cbs.knaw.nl) for M. gelida CBS $5272^{\mathrm{T}}$, M. frigida CBS $5270^{\mathrm{T}}$ and for $M r$. aquatica CBS $5443^{\mathrm{T}}$ and from Bab'eva et al. (2002), Xin and Zhou (2007) and Margesin and Fell (2008) for M. curviuscula CBS $9136^{\mathrm{T}}$, M. psychrophila AS $2.1971^{\mathrm{T}}$ and Mr. cryoconiti CBS $10834^{\mathrm{T}}$, respectively. In Table 2 (Supplementary data), only the physiological characteristics of the type strains were reported, but all the strains studied in this work that belonged to the same species showed similar results.

All the strains had maximum growth temperature lower than $20^{\circ} \mathrm{C}$ and they can be considered as psychrophilic; the only exception was $M$. curviuscula. This species had physiological, ecological and phylogenetic characteristics that suggested that it may not belong to the Mrakia genus
(Margesin and Fell 2008). For this reason, M. curviuscula was not considered in the following analysis. All the strains utilized D-xylose, L-arabinose, $\alpha, \alpha$-trehalose, salicin, raffinose, D-sorbitol, D-mannitol, D-gluconate, D-glucuronate and nitrate, but not erythritol; they produced starch-like compounds and they had positive diazonium blue B (DBB) and urease reactions. Mrakia species, strains of group 1 and group 4 produced teliospores, whilst in Mrakiella species and in strains of group 7 no teliospore formation was observed.

Some difference occurred between strains of group 1 and the most related species $M$. gelida as they grew on inulin, myo-inositol and biotin-free, thiamine-free and vitamin-free media whilst $M$. gelida did not do so. Strains CBS 8921, CBS 8909 and CBS 8910 were not able to utilize inulin, ethylamine, creatine and creatinine; these were assimilated by the closely related $M$. psychrophila. Numerous physiological tests differentiated the strains CBS 8917 and CBS 8924 from Mr. aquatica and $M r$. cryoconiti, belonging to the same cluster and these included growth on $\alpha$-methyl-D-glucoside, inulin, ribitol, galactitol, myo-inositol and citrate media.

Glucose and sucrose were fermented by all the Antarctic isolates examined in this study. This led to further experiments to test the potential of these strains for cold beer fermentation, details of which can be found at the end of the Supplementary data.

\section{Sexual state}

To further examine the mating potential in these clades, all strains within each group were streaked side-by-side on corn meal agar and streaked as mixed cultures. After incubation at $15^{\circ} \mathrm{C}$ for 3 weeks, they were stored at $6^{\circ} \mathrm{C}$ and, subsequently, observed after 2, 3, 6, 9 and 15 months. No clamp connections were observed in any of the strains.

In single strains, terminal and intercalary teliospores were occasionally observed in all the Mrakia species but not in the Mrakiella ones. Germination of the teliospores and basidiospores was observed in some cases. These observations were in agreement with the current literature according to which no clamp connections occur in any species of the Mrakia genus, and hyphal cells and teliospores of species belonging to this genus are uninucleate and develop directly from a single cell in the absence of mating. For Mrakiella strains, no sexual reproduction has been observed.

All the species considered in this paper belonging to the Mrakia/Mrakiella clade could be divided into two groups: Mrakia and Mrakiella species, telomorphic and anamorphic species. In addition, phylogenetic analysis confirmed and highlighted the division of the two genera at the top and at the bottom of the trees, respectively (Figs. 1, 2). 


\section{PAGE analysis of proteins}

One-dimensional polyacrylamide gel electrophoresis of whole-cell protein extracts was compared amongst 42 Mrakia isolates. All the strains showed similar or identical protein banding patterns to each other. From this analysis, 13 isolates that differed from each other in both colony appearance and protein fingerprint were chosen to represent the entire group (details of all 42 isolates are presented in Table 1 of the Supplementary data. Protein fingerprints of the 13 representative strains are presented in the Supplementary data Figures 27 and 28). The isolates were arranged according to their phylogenetic groups and these groups were run side-by-side for closer analysis. Although there was overall similarity in the protein fingerprints, each strain had unique protein banding patterns, but within each group the banding pattern was generally most similar to the other members of the designated group.

Some interesting observations came from the study of protein banding patterns. Regarding the strains belonging to group 1 (M. robertii), it was evident that CBS $8912^{\mathrm{T}}$ presented a different pattern compared from the other strains (Supplementary data Fig. 28). A possible explanation for the significant intraspecific variation is that CBS $8912^{\mathrm{T}}$ formed mycelia very early in its growth phase, whereas the other strains predominantly remained in the yeast budding phase. This may also be an explanation as to why Vancanneyt et al. (1992) found such high levels of intraspecific variation in their protein fingerprint study of the Mrakia species.

Group 4 (M. blollopis) had the highest intraspecific variation and also varied the most to the other groups, thus supporting the classification of this group as a distinct species. Additionally in both sequence analyses and protein fingerprint, CBS 8907 was the strain that varied the most as compared to the other members of the group.

Group 4 strains (M. blollopis) had a number of protein bands very similar to each other but not found in the other groups. It was very difficult to achieve a satisfactory protein extraction from CBS $8921^{\mathrm{T}}$ or to obtain the initial PCR product (for sequence analysis) as compared to the other strains. In all the protein extracts (in excess of 20), the protein concentration was always weak and the protein bands appeared unclear and degraded. This may have been due to high protease activity and/or a very tough cell wall that was resistant to breakage. It is interesting to note that CBS $8921^{\mathrm{T}}$ also had a different cell morphology (i.e. round cells) from the other Mrakia strains.

High levels of similarity between strains of Mrakia have been consistently reported in the literature, leading to their temporary classification as a single species. Although high levels of similarities were also found in this study, clustering of each species in various groups was also evident from the sequence and protein fingerprint analyses.

A comparison between group 7 (Mr. niccombsii) and group 8 ( $M r$. aquatica) protein fingerprint patterns (Supplementary data Fig. 29) found defined differences between each species, thus strengthening their classification as separate species.

Fatty acid analysis

Cells growing exponentially at $15^{\circ} \mathrm{C}$ were harvested and fatty acid profiles were analysed by gas liquid chromatography. The fatty acid percentages were similar amongst all strains tested although some differences were noted (Fig. 3a). In particular, $\mathrm{C}_{16: 1}$ (palmitoleic acid) was present in some strains and not in others. This variation was, however, also noted for CBS 8919 which had no detectable $\mathrm{C}_{16: 1}$ in the exponential phase extract, but $\approx 4 \% \mathrm{C}_{16: 1}$ in stationary phase (data not presented). It was noteworthy that the strains tested had high percentages of polyunsaturated fatty acids, on average around $45 \%$ linoleic acid $\left(\mathrm{C}_{18: 2}\right)$ and $20 \%$ linolenic acid $\left(\mathrm{C}_{18: 3}\right)$. These values were the highest percentage of polyunsaturated fatty acids observed amongst all the strains examined. The present results are consistent with the early observations of Watson (1987) who reported up to $49 \%$ linolenic acid in strains of Mrakia grown at $-1^{\circ} \mathrm{C}$. A high percentage of polyunsaturated fatty acids is, therefore, a characteristic feature of Mrakia species. Although there were some variations observed in the fatty acid compositions between logarithmic and stationary growth phase cells, there was little overall variation observed between them and no distinct trends were noted for the group as a whole.

All Mrakia strains had a high percentage of lipids present within the cells as demonstrated by staining with Nile red, a hydrophobic stain that selectively stains nonpolar compounds, such as lipids, under blue light bright yellow fluorescent. In Fig. 3b and c, lipid droplets within cells of CBS $8921^{\mathrm{T}}$ grown to the end of exponential phase are clearly visible using phase contrast (Fig. 3b). In some cells, the lipids appeared to be greater than $50 \%$ of the cellular volume. The same image illuminated with blue light highlighted the lipids as yellow fluorescent (Fig. 3c), showing the full extent of how much lipid was actually present within the cells.

For strains belonging to group 7 (Mr. niccombsi) and $M r$. aquatica, fatty acid profiles were analysed in extracts from cells in logarithmic and stationary growth phases (Fig. 4). In the three strains studied, the fatty acid profiles for palmitic acid $\mathrm{C}_{16: 0}(12-18 \%)$ and for stearic acid $\mathrm{C}_{18: 0}$ $(0-2 \%)$ were similar in both phases. However, some variation was apparent in the unsaturated fatty acid profiles for the two different growth phases. The percentage of oleic 
Fig. 3 a Graph of the fatty acid profile for strains of Mrakia species harvested in exponential growth phase. Key refers to CBS numbers. b, c Nile red stained light micrographs of CBS $8921^{\mathrm{T}}$. b Image taken using white light with phase contrast. c Image was additionally illuminated with blue light $(450-490 \mathrm{~nm})$ to induce fluorescence of the Nile red stained lipids
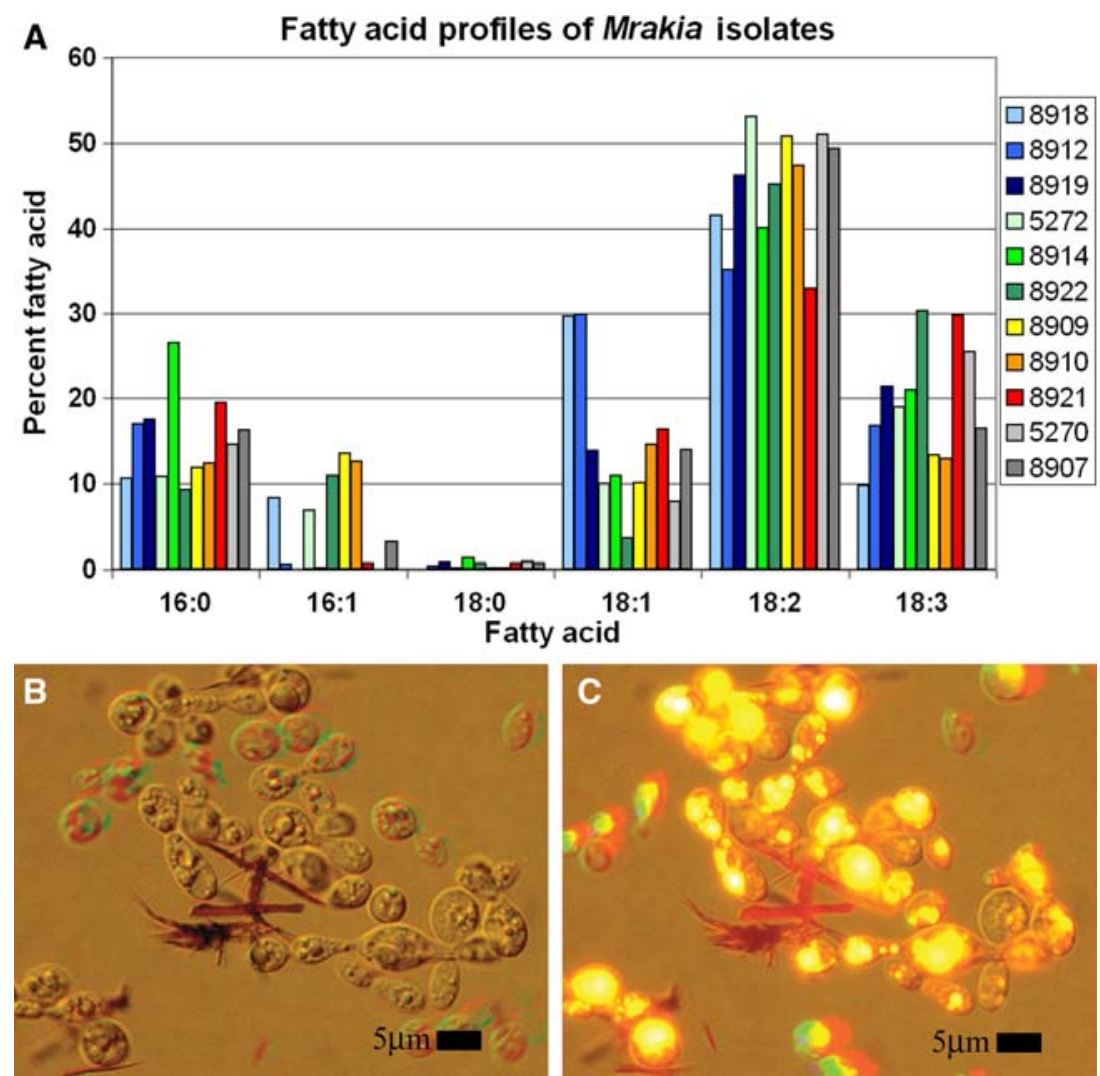

acid $\left(\mathrm{C}_{18: 1}\right)$ decreased when cultures reached the stationary phase and percentages of linoleic acid $\left(\mathrm{C}_{18: 2}\right)$ and linolenic acid $\left(\mathrm{C}_{18: 3}\right)$ increased correspondingly. This trend was also been observed in Cr. nyarrowii (Thomas-Hall and Watson 2002) and to a lesser extent in Cr. statzelliae (Thomas-Hall et al. 2002). There were significant differences in the fatty acid profile between the two species, with $\mathrm{Mr}$. aquatica having a higher percentage of linoleic acid and lower percentage of oleic acid. On the other hand, both strains of $M r$. niccombsii had relatively similar fatty acid percentages. These observations add support to the proposal that Mr. niccombsii is a distinct species from Mr. aquatica.

\section{Description of new species}

Latin diagnosis of Mrakia robertii Thomas-Hall et Turchetti sp. nov.

Mrakia robertii ex Vestfold Hills Davis Base, Antarctica et ex Alpe Italica inventus est. In medio liquido YEP, post 7 dies, $15^{\circ} \mathrm{C}$, cellulae vegetativae globosae aut ovoidae, singulae aut binae gemmationis causa [(1.5-4.5) $\times(2-7 \mu \mathrm{m})]$ sunt. Flosculi polares sunt, cicatrices relinquendo. In YEP agaro, post 21 dies, $6^{\circ} \mathrm{C}$, coloniae rotundae albidae aut cremae in colore, infimo-convexae, glabrae pleraeque et butyraceae, cum margo erosa aliquando quia hyphae et pseudohyphae

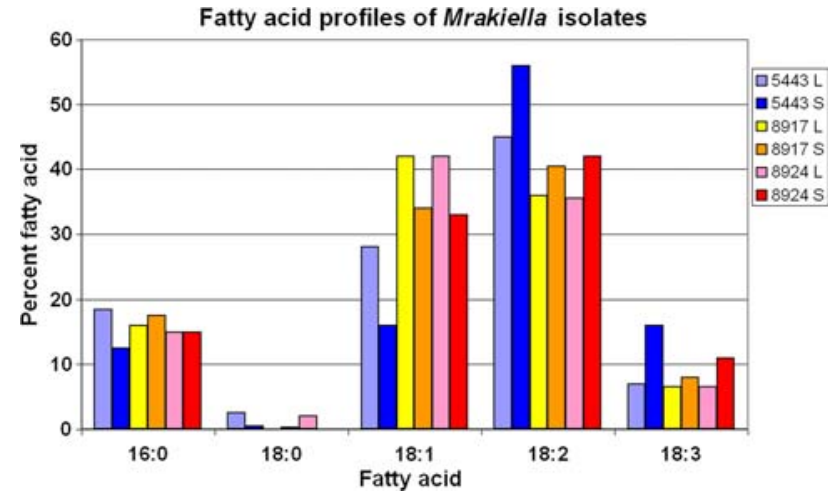

Fig. 4 Graph of the fatty acid profile for Mrakiella aquatica (CBS $5543^{\mathrm{T}}$ ) and Mrakiella niccombsii (CBS $8917^{\mathrm{T}}$ and CBS 8924). Key refers to CBS numbers; cells were grown and harvested in exponential growth phase $(L)$ and in stationary phase $(S)$

membranaceae formantur. Teliosporae intercalares aut terminales observantur; terminales sporidia cum promycelio ex germinantis teliosporis procreantur. Glucosum, sucrosum, maltosum (lente) et raffinosum (lente) fermentantur at non galactosum nec lactosum. Glucosum, galactosum, sucrosum, maltosum, cellobiosum, trehalosum, melibiosum, melezitosum, raffinosum, ribitolum, D-mannitolum, D-glucitolum, D-gluconatum, D-glucuronatum, xylosum, L-arabinosum, L-rhamnosum, D-glucosaminum, $N$-acetyl glucosaminum, salicinum, acidum citricum, inositolum, L-sorbosum 
(exigue), inulinum (exigue), amylum solubile (exigue), D-ribosum (exigue), ethanolum (exigue), acidum succinicum (exigue), D-arabinosum (exigue), a-methyl-D-glucosidum (exigue) et hexadecanum (exigue) assimilat. Lactosum, methanolum, glycerolum, erythritolum, galactitolum et DL-lacticum non assimilat. Biotina et thiamina externa ad crescentiam necessaria non est. Crescit sine vitaminis. Nitratum assimilatur. Materia amyloidea iodhophila formatur. Urea finditur. Incrementum in medio $50 \%$ glucosum non respondet. Diazonium caeruleum B positivum. Liquatio gelatinis respondet. Incrementum ad $1-20^{\circ} \mathrm{C}$ respondet, ad $25^{\circ} \mathrm{C}$ non respondet; incrementum maximum ad $15-18^{\circ} \mathrm{C}$ est. Typus CBS $8912^{\mathrm{T}}$ in collectione zymotica Centraalbureau voor Schimmelcultures depositus est.

\section{Description of Mrakia robertii Thomas-Hall} \& Turchetti sp. nov.

Mrakia robertii (ro'ber.ti.i L. gen. Sing. masc. n. robertii of Robert, referring to Vincent Robert, yeast biologist at the Centraalbureau voor Schimmelcultures at Utrecht, The Netherlands, in whose honour the species is named).

Seven strains are presented: CBS $8912^{\mathrm{T}}$, isolated from soil and lichen taken from Mossell Lake $\left(68^{\circ} 38^{\prime} 20^{\prime \prime} \mathrm{S}\right.$, $\left.78^{\circ} 17^{\prime} 53^{\prime \prime} \mathrm{E}\right)$, CBS 8918, isolated from soil taken from Moss Cirque $\left(68^{\circ} 27^{\prime} 57^{\prime \prime} \mathrm{S}, 78^{\circ} 24^{\prime} 58^{\prime \prime} \mathrm{E}\right)$ and CBS 8919, isolated from soil and lichen taken from Lichen Valley $\left(68^{\circ} 29^{\prime} 48^{\prime \prime} \mathrm{S}, 78^{\circ} 25^{\prime} 08^{\prime \prime} \mathrm{E}\right)$, all three within Vestfold Hills area of Davis Base, Antarctica. DBVPG 4728 isolated from subglacial sediments and DBVPG 4775 from melting water of Forni Glaciers (Italian Alps), DBVPG 4752 isolated from subglacial sediment and DBVPG 4782 from melting water of Sforzellina Glaciers (Italian Alps). In YEP broth after 1 week at $15^{\circ} \mathrm{C}$, the cells were ovoid-elongate, occurred singly or in parent-bud pairs and varied in size from (1.5-4.5) $\times(2-7) \mu \mathrm{m}$. Budding was polar leaving raised bud scars (Fig. 5a). After 3 weeks at $6^{\circ} \mathrm{C}$ on YEP, colonies were a white cream colour, butyrous, generally smooth, convex and circular and may be surrounded by hyphae, with both pseudo and true hyphae forming (Sup. data Figures 6-12). Teliospores were observed after 2 months at $15^{\circ} \mathrm{C}$ terminally and intercalary on corn meal agar (Fig. 5b, c), malt agar and carbon base agar, germinating teliospores had one-celled probasidium with terminal sporidia. Growth response to corn meal agar was weak. Growth on malt agar was slightly weaker to that on YEP and similar colonies were formed.

Carbon compounds assimilated: positive for glucose, galactose, sucrose, maltose, cellobiose, trehalose, melibiose, raffinose, melezitose, ribitol, D-mannitol, D-glucitol, D-gluconate, D-glucuronate and biotin-free media; weak or positive for D-xylose, L-arabinose, L-rhamnose, D-glucosamine, $N$-acetyl-D-glucosamine, salicin, citrate,
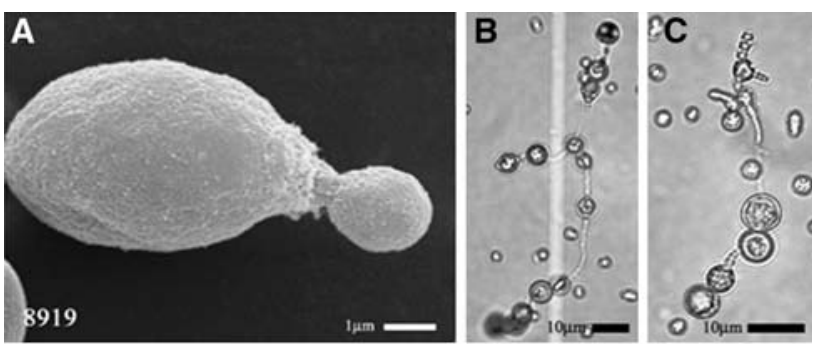

Mrakia robertii

Type strain: CBS 8912

Origins of strains: Antarctica, Alps

YEP broth: cells ovoidal-elongate, singly or in pairs

Budding: polar

Size: $1.5-4.5 \times 2-7 \mu \mathrm{m}$

Colonies in YEP Agar: white-cream colour, butyrous, smooth, convex, circular, with treu/pseudo hyphae

Teliospore: present, intercalary and terminally
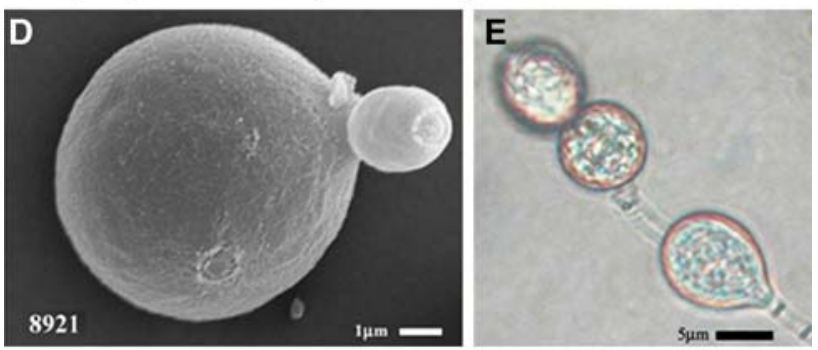

Mrakia blollopis

Type strain: CBS 8921

Origins of strains: Antarctica

YEP broth: cells spheroidal to ovoidal, singly or in pairs

Budding: polar

Size: $2-4.5 \times 3.5-7 \mu \mathrm{m}$

Colonies in YEP Agar: from white-cream to yellow-white colour, butyrous, smooth, convex, circular, with treu/pseudo hyphae

Teliospore: present, intercalary and terminally

Fig. 5 a Scanning electron micrograph (SEM) of Mrakia robertii CBS 8919 vegetative cells, bar $1 \mu \mathrm{m}$. b, c Intercalary teliospores of Mrakia robertii CBS 8919 on carbon base agar with no added nitrogen source, bar $10 \mu \mathrm{m}$. d SEM of Mrakia blollopis CBS $8921^{\mathrm{T}}$ cells from a 2-month-old YEP culture, bar $1 \mu \mathrm{m}$. e Slide of Mrakia blollopis CBS $8921^{\mathrm{T}}$ intercalary teliospores after 2 months on malt agar bar $5 \mu \mathrm{m}$

inositol, $10 \% \mathrm{NaCl}-5 \%$ glucose, vitamin-free and thiamine-free media; weak for L-sorbose, inulin, soluble starch, D-ribose, ethanol and succinate; weak or negative for D-arabinose, $\alpha$-methyl-D-glucoside and hexadecane; negative for lactose, methanol, glycerol, erythritol, galactitol and DL-lactate. Nitrate is assimilated. Starch-like compounds were formed, DBB and urease reactions were positive. Growth on $50 \%$ (w/w) glucose yeast extract agar was negative. Gelatin may or may not be liquefied. Glucose and sucrose were fermented; maltose and raffinose fermentation was slow; galactose and lactose were not fermented. The maximum growth temperature was $20^{\circ} \mathrm{C}$ and optimal growth temperature was $15-18^{\circ} \mathrm{C}$. These strains were deposited also in the collection of the Yeast Division of the Centraalbureau voor Schimmelcultures, Uppsalalaan 8, 3584 CT Utrecht, the Netherlands, as CBS 
8912 ${ }^{\mathrm{T}}$, CBS 8918, CBS 8919, CBS 10983, CBS 10985, CBS 11002 and CBS 11003.

\section{Latin diagnosis of Mrakia blollopis}

Thomas-Hall sp. nov.

Mrakia blollopis ex Vestfold Hills Davis Base, Antarctica inventus est. In medio liquido YEP, post 7 dies, $15^{\circ} \mathrm{C}$, cellulae vegetativae globosae aut ovoidae, singulae aut binae gemmationis causa $[(2-4) \times(3.5-7) \mu \mathrm{m}]$ sunt. Flosculi polares sunt, cicatrices relinquendo. In YEP agaro, post 21 dies, $6^{\circ} \mathrm{C}$ coloniae albidae aut cremae in colore, rotundae, convexae, butyraceae et glabrae cum margo erosa quia hyphae membranaceae formantur. Hyphae et pseudohyphae intra et super agaro ex coloniis formantur. Teliosporae intercalares aut terminales observantur; terminalia sporidia cum promycelio ex germinantis teliosporis procreantur. Glucosum et sucrosum fermentantur at non galactosum, maltosum, lactosum nec raffinosum. Glucosum, galactosum, sucrosum, maltosum, cellobiosum, trehalosum, melibiosum, melezitosum, raffinosum, L-arabinosum, ethanolum, ribitolum, D-glucitolum, D-gluconatum, D-glucuronatum, xylosum, D-ribosum, D-glucosaminum, D-mannitolum, salicinum, acidum citricum, inositolum, amylum solubile (variabile), glycerolum (variabile), acidum succinicum (variabile), L-sorbosum (exigue), lactosum (exigue), L-rhamnosum (exigue), $\mathrm{N}$-acetyl glucosaminum (exigue), D-arabinosum (exigue), methanolum (exigue), erythritolum (exigue), galactitolum (exigue), DL-lacticum (exigue), a-methyl-D-glucosidum (exigue) et hexadecanum (exigue) assimilat. Inulinum non assimilat. Biotina et thiamina externa ad crescentiam necessaria non est. Crescit exigue sine vitaminis. Nitratum assimilatur. Materia amyloidea iodhophila formatur. Urea finditur. Incrementum in medio 50\% glucosum non respondet. Diazonium caeruleum B positivum. Liquatio gelatinis respondet. Incrementum ad $4-20^{\circ} \mathrm{C}$ respondet, ad $25^{\circ} \mathrm{C}$ non respondet; incrementum maximum ad $15-18^{\circ} \mathrm{C}$ est. Typus CBS $8921^{\mathrm{T}}$ in collectione zymotica Centraalbureau voor Schimmelcultures depositus est.

\section{Description of Mrakia blollopis Thomas-Hall sp. nov.}

Mrakia blollopis (blol'lo.pis L. gen. neut. n. blollopis of Blollop, referring to the name of the "Antarctic" beer that was produced using strains of this yeast species).

Three strains are presented: CBS $8921^{\mathrm{T}}$, isolated from soil taken from Marine Plain $\left(68^{\circ} 37^{\prime} 30^{\prime \prime} \mathrm{S}, 78^{\circ} 7^{\prime} 4^{\prime \prime} \mathrm{E}\right)$, CBS 8909 and CBS 8910, both isolated from soil taken Moss Cirque $\left(68^{\circ} 27^{\prime} 57^{\prime \prime} \mathrm{S}, 78^{\circ} 24^{\prime} 58^{\prime \prime} \mathrm{E}\right)$, from the Vestfold Hills area of Davis Base, Antarctica. In YEP broth after 1 week at $15^{\circ} \mathrm{C}$, the cells were spheroidal to ovoid, occurred singly or in parent-bud pairs and measure $(2-4) \times(3.5-7) \mu \mathrm{m}$.
Budding was polar leaving raised bud scars (Fig. 5d). After 3 weeks at $6^{\circ} \mathrm{C}$ on YEP, colonies were white cream colour and mature (4-5 weeks) into dull yellow-white cream colour. Butyrous colonies were smooth, convex and circular with surrounding hyphae. Pseudo- and true hyphae extended into and along agar, thus giving each colony a sun-like appearance (Sup. data Figures 13-15). Teliospores were observed after 2 months at $15^{\circ} \mathrm{C}$ terminally and intercalary the hyphae on corn meal agar (Fig. 5e), malt agar and carbon base agar. Germinating teliospores had a one-celled probasidium with terminal sporidia. Growth response to corn meal agar was weak. Growth on malt agar was slightly weaker to that on YEP, but similar colonies were formed.

Carbon compounds assimilated: positive for glucose, galactose, sucrose, maltose, cellobiose, trehalose, melibiose, raffinose, melezitose, L-arabinose, ethanol, ribitol, D-glucitol, D-gluconate, D-glucuronate and biotin-free media; weak or positive for D-xylose, D-ribose, D-glucosamine, D-mannitol, salicin, citrate, inositol, $10 \% \mathrm{NaCl}-5 \%$ glucose and thiamine-free media; weak for L-sorbose, lactose, L-rhamnose, $\mathrm{N}$-acetyl-D-glucosamine and vitamin-free media; variable for soluble starch, glycerol and succinate; weak or negative for D-arabinose, methanol, erythritol, galactitol, DL-lactate, $\alpha$-methyl-D-glucoside and hexadecane; negative for inulin. Nitrate assimilation was positive. Starch-like compounds were formed; DBB and urease reactions were positive. Growth on $50 \%(\mathrm{w} / \mathrm{w})$ glucose yeast extract agar was negative. Gelatin was liquefied. Glucose and sucrose were fermented. Galactose, maltose, lactose and raffinose were not fermented. The maximum growth temperature was $20^{\circ} \mathrm{C}$ and optimal growth temperature was $15-18^{\circ} \mathrm{C}$. These strains were deposited in the collection of the Yeast Division of the Centraalbureau voor Schimmelcultures, Uppsalalaan 8, 3584 CT Utrecht, the Netherlands, as CBS $8921^{\mathrm{T}}$, CBS 8909 and CBS 8910.

\section{Latin diagnosis of Mrakiella niccombsii}

Thomas-Hall sp. nov.

Mrakiella niccombsii ex Vestfold Hills Davis Base, Antarctica inventus est. In medio liquido YEP, post 7 dies, $15^{\circ} \mathrm{C}$, cellulae vegetativae cylindratae aut ovoidae, singulae aut binae gemmationis causa $[(2-3) \times(4-7) \mu \mathrm{m}]$ sunt. Flosculi polares sunt, cicatrices prominentes relinquendo. In YEP agaro, post 21 dies, $6^{\circ} \mathrm{C}$, coloniae rotundae, albidae aut cremae in colore, infimo-convexae, glabrae et butyraceae, cum margo aliquando erosa quia pseudohyphae intra et super agaro formantur. Status sexualis non observatur. Glucosi fermentatio nulla. Glucosum, sucrosum, maltosum, raffinosum, xylosum, D-gluconatum, L-sorbosum, cellobiosum, trehalosum, melezitosum, D-ribosum, L-rhamnosum, D-glucosaminum, ethanolum, glycerolum, D-glucitolum, 
salicinum, D-glucuronatum, erythritolum (variabile), galactosum (exigue), lactosum (exigue), melibiosum (exigue), inulinum (exigue), amylum solubile (exigue), L-arabinosum (exigue), D-arabinosum (exigue), $N$-acetyl glucosaminum (exigue), D-mannitolum (exigue), D-glucitolum (exigue), a-methyl-D-glucosidum (exigue), succinicum (exigue), acidum citricum (exigue) et inositolum (exigue) assimilat. Methanolum, ribitolum, DL-lacticum et hexadecanum non assimilat. Vitaminae externae ad crescentiam necessariae non sunt. Crescit sine biotina. Nitratum assimilatur. Materia amyloidea iodhophila formatur. Urea finditur. Incrementum in medio 50\% glucosum non respondet. Diazonium caeruleum B positivum. Liquatio gelatinis respondet. Incrementum ad $1-20^{\circ} \mathrm{C}$ respondet, ad $25^{\circ} \mathrm{C}$ non respondet; incrementum maximum ad $15-18^{\circ} \mathrm{C}$ est. Typus CBS $8917^{\mathrm{T}}$ in collectione zymotica Centraalbureau voor Schimmelcultures depositus est.

\section{Description of Mrakiella niccombsii}

Thomas-Hall sp. nov.

Mrakiella niccombsii (nic.comb'si.i L. gen. sing. masc. $\mathrm{n}$. niccombsii of Nicolas Combs, referring to Nicolas Combs, retired science teacher of Murwillumbah High School, in whose honour the species is named).

Two strains are presented: CBS $8917^{\mathrm{T}}$ from lichen taken from Teat Lake $\left(68^{\circ} 37^{\prime} 17^{\prime \prime} \mathrm{S}, 78^{\circ} 19^{\prime} 29^{\prime \prime} \mathrm{E}\right)$ and CBS 8924 from soil and lichen taken from Moss Cirque $\left(68^{\circ} 27^{\prime} 57^{\prime \prime} \mathrm{S}\right.$, $78^{\circ} 24^{\prime} 58^{\prime \prime} \mathrm{E}$ ), both were isolated from the Vestfold Hills area of Davis Base, Antarctica. In YEP broth after 1 week at $15^{\circ} \mathrm{C}$, the cells were elongate to ovoid, occurred singly or in parent-bud pairs and measure $(2-3) \times(4-7) \mu \mathrm{m}$ (Fig. 6). Budding was polar leaving a raised protuberance for bud scars at the pole. After 3 weeks at $6^{\circ} \mathrm{C}$ on YEP, colonies were a white cream colour, butyrous in texture, circular, smooth and convex. Pseudohyphae occasionally extended into and in the surface of agar in old cultures (2-3 months). No sexual state was observed on YEP agar, corn meal agar, malt agar nitrogen base agar or carbon base agar. Growth response to corn meal agar was weak. Growth on malt agar was slightly weaker to that on YEP and similar colonies were formed.

Carbon compounds assimilated: positive for glucose, sucrose, maltose, raffinose, D-xylose, D-gluconate, $10 \%$ $\mathrm{NaCl}-5 \%$ glucose and biotin-free media; weak to positive for L-sorbose, cellobiose, trehalose, melezitose, D-ribose L-rhamnose, D-glucosamine, ethanol, glycerol, galactitol, salicin, D-glucuronate; weak for galactose, lactose, melibiose, inulin, soluble starch, L-arabinose, D-arabinose, $N$-acetyl-D-glucosamine, D-mannitol, D-glucitol, $\alpha$-methylD-glucoside, succinate, citrate, inositol; variable for erythritol and negative for methanol, ribitol, DL-lactate, hexadecane, vitamin-free and thiamine-free media. Nitrate assimilation

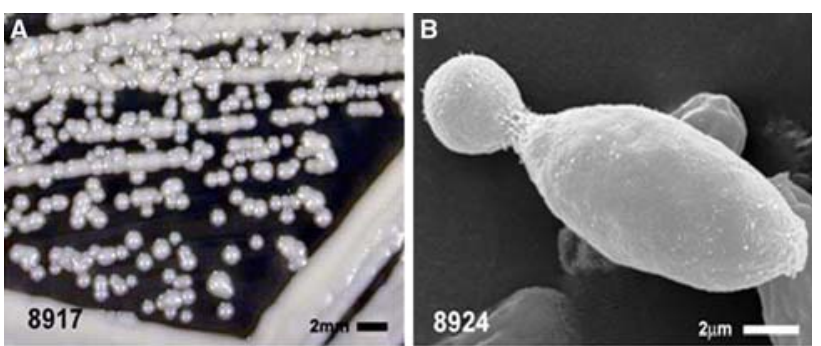

Mrakiella niccombsii

Type strain: CBS 8917

Origins of strains: Antarctica

YEP broth: cells ovoidal-elongate, singly or in pairs

Budding: polar

Size: $2-3 \times 4-7 \mu \mathrm{m}$

Colonies in YEP Agar: white-cream colour, butyrous, smooth, convex, circular, with pseudo hyphae

Teliospore: absent

Fig. 6 a Colonies formation of Mrakiella niccombsii CBS $8917^{\mathrm{T}}$, bar $2 \mathrm{~mm}$. b SEM of CBS 8924 vegetative cells, bar $2 \mu \mathrm{m}$

was positive. Starch-like compounds were formed; DBB and urease reactions were positive. Growth on $50 \%(\mathrm{w} / \mathrm{w})$ glucose yeast extract agar was negative. Gelatin was liquefied. Glucose was not fermented.

\section{Discussion}

Glaciers represent a unique habitat, which can be considered an unexplored reservoir for unknown microbial species. Due to global warming determining the melting of glaciers in every region of the world, entire cold ecosystems are in danger of disappearing (Oerlemans et al. 1998). In this context, the isolation and ex situ conservation of psychrophilic microorganisms can be seen as a tool for avoiding their possible extinction. The relevance of the present paper is related to the description of the microbial biodiversity of eukaryotic populations sharing such cold environments giving an increased knowledge about a few previously undescribed yeast species, and to hypothesize their role in this unusual habitat.

The physiological, morphological and phylogenetic characteristics, as well as the fatty acid analysis and protein patterns of each strain studied, supported the identification of three new species: Mrakia robertii sp. nov., Mrakia blollopis sp. nov. and Mrakiella niccombsii sp. nov. The phylogenetic position of the Mrakia clade within the Cystofilobasidiales is well described by Margesin and Fell (2008), but the description of three new species belonging to the same clade required a revision of the phylogenetic assessment. Table 1 and Fig. 2 explained the proposed grouping of the clade.

The Mrakia/Mrakiella clade is almost entirely composed of strains isolated from cold environments (e.g. 
Antarctic, Greenland, Alps, Iceland). A number of uncultured strains were also included in the phylogenetic analysis, all of them originated from Greenland (Depriest et al. 2000b). The particular climate condition of these habitats determined the presence of a high percentage of psychrophilic yeasts, whilst other environmental factors that may differ from one place to the other, such as presence and amount of water, availability of organic energy, salt concentration, frequency of freeze-thaw cycles, could be responsible of the creation of specific niches and, consequently, the occurrence of specific microorganisms (Depriest et al. 2000b; Vishniac 2006; Turchetti et al. 2008). The novel species described in this paper are composed of strains isolated from glacial environments. In particular, the strains belonging to $M$. robertii were isolated from two distant environments: 11 strains coming from Antarctica (Vestvold Hills) and 14 strains from the Italian Alps, all with similar physiological and molecular characteristics. The origin from distinct geographical areas of these species suggests that the habitats of the two localities although on different continents may be characterized by the same environmental attributes and represent a similar niche able to select specific microbiotes. Whilst the ecological role of these yeast species in cold environments remains unknown. Their heterotrophic metabolism and additionally their ability to degrade organic macromolecules (Turchetti et al. 2008) through the secretion of extracellular hydrolytic cold-adapted enzymes may suggest their potential auxiliary role as biogeochemical nutrient recyclers in glacial environments.

The adaptation of psychrophilic yeast species to cold environments can be reflected in their structural and biochemical characteristics, e.g. production of cold-adapted enzymes, cryoprotectant wall carbohydrates as well as higher amounts of polyunsaturated fatty acids in cytoplasmic membranes (Vishniac 2006). The strains studied in this work also exhibited a high amount of intracellular lipids. A possible application of this characteristic is the potential use of such strains as biofactories, able to turn carbon sources into lipids at low temperature, which could then be used to synthesize biofuels. The strains studied in this work showed the production of lipids that are ideal in fatty acyl chain length and unsaturation to be conversed into biodiesel, with similar properties to that of sunflower oil. Biodiesel made from such feedstock has excellent cold flow properties. This is fortuitous as Mrakia species are psychrophilic and the initial production of the biomass would be best suited to colder climates.

All the Mrakia strains (except M. curviuscula) ferment glucose and sucrose and this led to further experiments to test the potential of these strains for cold beer fermentation. Four strains (CBS 8907, 8910, 8911 and 8918 representing species of M. frigida, M. blollopis, M. gelida and
$M$. robertii, respectively) were used as the yeast inoculum in a home brew kit with a commercial malt extract and 5\% sucrose. Each strain readily fermented at 6 and $15^{\circ} \mathrm{C}$, but could not complete the fermentation of all the sucrose. It was later determined that alcohol above $2 \%$ inhibited the growth of these Mrakia strains and thus they were unable to convert all the sucrose to alcohol.

Acknowledgments This work was supported in part by the Australian Research Council, a UNE postgraduate scholarship, the SYNTHESYS Project (http://www.synthesys.info/) which is financed by the European Community Research Infrastructure Action under the FP6 "Structuring the European Research Area" Programme, from FEMS (Federation of European Microbiological Societies) and from MIUR (PRIN projects 2008/09).

Open Access This article is distributed under the terms of the Creative Commons Attribution Noncommercial License which permits any noncommercial use, distribution, and reproduction in any medium, provided the original author(s) and source are credited.

\section{References}

Bab'eva IP, Lisichkina GA, Reshetova IS, Danilevich VN (2002) Mrakia curviuscula sp. nov.-a new species of psychrophilic yeast from forest substrates. Mikrobiologiya 71:526-532

Birgisson H, Delgado O, Garcia Arroyo L, Hatti-Kaul R, Mattiasson B (2003) Cold-adapted yeasts as producers of cold-active polygalacturonases. Extremophiles 7:185-193

Brizzio S, Turchetti B, de García V, Libkind D, Buzzini P, van Broock M (2007) Extracellular enzymatic activities of basidiomycetous yeasts isolated from glacial and subglacial waters of northwest Patagonia (Argentina). Can J Microbiol 53:519_ 525

de García V, Brizzio S, Libkind D, Buzzini P, van Broock M (2007) Biodiversity of cold-adapted yeasts from glacial meltwater rivers in Patagonia, Argentina. FEMS Microbiol Ecol 59:331-341

Depriest PT, Ivanova NV, Fahselt D, Alstrup V, Gargas A (2000a) Sequences of psychrotrophic yeast from Antarctica. Extremophiles 2:41-50

Depriest PT, Ivanova NV, Fahselt D, Alstrup V, Gargas A (2000b) Sequences of psychrophilic fungi amplified from glacier-preserved ascolichens. Can J Bot 78:1450-1459

Di Menna ME (1966a) Three new yeast from Antarctic soils: Candida nivalis, Candida gelida and Candida frigida spp. Antonie Leeuwenhoek 32:25-28

Di Menna ME (1966b) Yeasts in Antarctic soil. Antonie Leeuwenhoek 32:29-38

Diaz MR, Fell JW (2000) Molecular analyses of the IGS and ITS regions of rDNA of the psychrophilic yeasts in the genus Mrakia. Antonie Leeuwenhoek 77:7-12

Hanschke R, Schauer F (1996) Improved ultrastructural preservation of yeast cells for scanning electron microscopy. J Microsc 184:81-87

Komagata K, Nakase T (1965) New species of the genus Candida isolated from frozen foods. J Gen Appl Microbiol 11:255-267

Kourkoutas Y, Koutinas A, Kanellaki M, Banat I, Marchant R (2002) Continuous wine fermentation using a psychrophilic yeast immobilized on apple cuts at different temperatures. Food Microbiol 19:127-134 
Lambo A, Patel T (2006) Cometabolic degradation of polychlorinated biphenyls at low temperature by psychrotolerant bacterium Hydrogenophaga sp. IA3-A. Curr Microbiol 53:48-52

Liu D, Schmid R, Rusnak M (2006) Functional expression of Candida antarctica lipase B in the Escherichia coli cytoplasm-a screening system for a frequently used biocatalyst. Appl Microbiol Biotechnol 72:1024-1032

Maksimova IA, Chernov IIu (2004) Community structure of yeast fungi in forest biogeocenoses. Mikrobiologiia 73:558-566

Margesin R, Fell J (2008) Mrakiella cryoconiti gen. nov., sp. nov., a psychrophilic, anamorphic, basidiomycetous yeast from alpine and artic habitats. Int J Syst Evol Microbiol 58:2977-2982

Margesin R, Zacke G, Schinner F (2002) Characterization of heterotrophic microorganisms in alpine glacier cryoconite. Arct Antarct Alp Res 34:88-93

Margesin R, Fauster V, Fonteyne PA (2005) Characterization of coldactive pectate lyases from psychrophilic Mrakia frigida. Lett Appl Microbiol 40:453-459

Nakagawa T, Nagaoka T, Taniguchi S, Miyaji T, Tomizuka N (2004) Isolation and characterization of psychrophilic yeasts producing cold-adapted pectinolytic enzymes. Lett Appl Microbiol 38:383387

Oerlemans J, Anderson B, Hubbard A, Huybrechts Ph, Johannesson T, Knap WH, Schmeits M, Stroeven AP, van de Wal RSW, Wallinga J, Zuo Z (1998) Modelling the response of glaciers to climate warming. Clim Dyn 14:267-274

Panikov NS, Sizova MV (2007) Growth kinetics of microorganisms isolated from Alaskan soil and permafrost in solid media frozen down to $-35^{\circ} \mathrm{C}$. FEMS Microbiol Ecol 59:500-512

Pfeffer J, Richter S, Nieveler J, Hansen CE, Rhlid R, Schmid R, Rusnak M (2006) High yield expression of lipase A from Candida antarctica in the methylotrophic yeast Pichia pastoris and its purification and characterization. Appl Microbiol Biotechnol 72:931-938

Poliakova AV, Chernov IYu, Panikov NS (2001) Yeast biodiversity in hydromorphic soils with reference to grass-Sphagnum swamp in Western Siberia and the hammocky tundra region (Barrow, Alaska). Mikrobiologiya 70:714-720

Raspor P, Zupan J (2006) Yeasts in extreme environments. In: Peter G, Rosa C (eds) The yeast handbook. Biodiversity and ecophysiology of yeasts. Springer, Berlin, pp 371-417
Rule DC (1996) Direct transesterification of total fatty acids of adipose tissue, and freeze-dried muscle and liver with borontrifluoride in methanol. Meat Sci 46:23-32

Scorzetti G, Petrescu I, Yarrow D, Fell JW (2000) Cryptococcus adeliensis sp. nov., a xylanase producing basidiomycetous yeast from Antarctica. Antonie Leeuwenhoek 77:153-157

Swan TM, Watson K (1997) Membrane fatty acid composition and membrane fluidity as parameters of stress tolerance in yeast. Can J Microbiol 43:70-77

Tamura K, Dudley J, Nei M, Kumar S (2007) MEGA4: Molecular Evolutionary Genetics Analysis (MEGA) Software Version 4.0. Mol Biol Evol 24:1596-1599

Thomas-Hall S, Watson K (2002) Cryptococcus nyarrowii sp. nov., a basidiomycetous yeast from Antarctica. Int J Syst Evol Microbiol 52:1033-1038

Thomas-Hall S, Watson K, Scorzetti G (2002) Cryptococcus statzelliae sp. nov. and three novel strains of Cryptococcus victoriae, yeasts isolated from Antarctic soils. Int J Syst Evol Microbiol 52:2303-2308

Turchetti B, Buzzini P, Goretti M, Branda E, Diolaiuti G, D'Agata C, Smiraglia C, Vaughan-Martini A (2008) Psychrophilic yeasts in glacial environments of Alpine glaciers. FEMS Microbiol Ecol 63:73-83

Vancanneyt M, Lerberge EV, Berny FF, Hennebert G, Kersters K (1992) The application of whole-cell protein electrophoresis for the classification and identification of Basidiomycetous yeast species. Antonie Leeuwenhoek 61:69-78

Vishniac HS (2006) Yeast biodiversity in the Antarctic. In: Peter G, Rosa C (eds) The yeast handbook. Biodiversity and ecophysiology of yeasts. Springer, Berlin, pp 419-440

Watson K (1987) Temperature relationships. In: Rose AH, Harrison JS (eds) The yeasts, vol 2, 2nd edn. Academic Press, London, pp 41-71

Welander U (2005) Microbial degradation of organic pollutants in soil in a cold climate. Soil Sediment Contam 14:281-291

Xin MX, Zhou PJ (2007) Mrakia psychrophila sp. nov., a new species isolated from Antarctic soil. J Zhejiang Univ Sci B 8:260-265

Yarrow D (1998) Methods for the isolation and identification of yeasts. In: Kurtzman CP, Fell JW (eds) The yeasts, a taxonomic study, 4th edn. Elsevier, Amsterdam, pp 77-100 